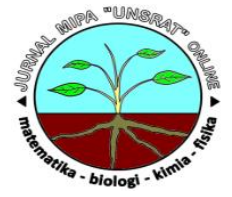

\title{
Keanekaragaman Amphibi Di Areal Persawahan Kota Tondano Kabupaten Minahasa Provinsi Sulawesi Utara
}

\author{
Yohaneta Karesa*, Deidy Y. Katilia,Marnix L. Langoya \\ aprogram Studi Biologi, Fakultas Matematika dan IImu Pengetahuan Alam, \\ Universitas Sam Ratulangi Indonesia
}

K A T A K U N C I

IndeksKeanekaragaman

Shannon-Wiener, Amphibi.

\begin{abstract}
A B S T R A K
Persawahan merupakan habitat yang baik bagi kehidupan amphibi. Amphibi memiliki fungsi ekologis sebagai penyeimbang ekosistem dan sebagai bioindikator lingkungan. Penilitian ini bertujuan untuk menganalisis keanekaragaman amphibi di areal persawahan Boleuvard Kota Tondano berdasarkan nilai indeks Shannon-Wiener. Penelitian ini menggunakan metode Line Transect yang dilaksanakan pada bulan Januari-Desember 2018. Nilai indeks keanekaragaman Shannon-Wiener pada transek satu H' 0,782, transek dua $H^{\prime} 1,208$ dan transek tiga $H^{\prime} \quad 1,139$. Berdasarkanhasilpenelitianterdapat lima spesies yang ditemukanya itu Bufo melanostictus, Rana cancrifora, Rana chalconota, Fejevarya limnocharis, dan Hylarana nicobariensis. Berdasarkan kategori indeks Shannon-wiener keanekaragaman amphibi di areal persawahan Tondano termasuk dalam kategori sedang.

A B S T R A C T

Rice fields are good habitat for amphibian life. Amphibians have an ecological function as a counterweight to ecosystems and as an environmental bioindicator. This research tries to analyze the amphibians in the Boleuvard rice field area of Tondano City based on the Shannon-Wiener index value. This study uses the Path Transect method which was carried out in January - December 2018. The index value of the Shannon-Wiener contribution to habitatone $\mathrm{H}$ '0,782, habitat two $H^{\prime} 1,208$ and habitat three $H^{\prime}$ 1,139. Based on the results of the study found five species found, namely Bufo melanostictus, Rana cancrifora, Rana chalconota, Fejevarya limnocharis, and Hylarana nicobariensis. Based on the Shannon-wiener index category the various amphibians in the Tondano rice field area are included in the medium category.
\end{abstract}

\begin{tabular}{ll} 
K E Y W O R D S & \\
\hline Shannon-Wiener $\quad$ Diversity
\end{tabular}

Index, Amphibians.
TERSEDIA ONLINE

31 Oktober 2019

\section{Pendahuluan}

Keberadaan populasi amphibi menjadi perhatian dunia International Union for Conservation of Nature (IUCN) and Natural Resources yang pada tahun 2007 telah melakukan evaluasi terhadap 5743 spesies amphibi di dunia dengan melibatkan lebih dari 500 peneliti dari 60 negara, termasuk Indonesia dari hasilnya menunjukkan bahwa 1856 spesies amphibi terancam punah. Sebanyak 9 spesies punah sejak tahun 1980, sementara 113 spesies tidak ditemukan lagi akhir-akhir ini dan 43\% dari semua spesies mengalami penurunan populasi
(Stuart et al., 2004). Turunnya populasi amphibi disebabkan oleh banyak faktor salah satunya yaitu pemanfaatan berlebihan (Kusrini, 2007). Tekanan terhadap populasi katak dan kodok akan terus berlanjut dan bukan tidak mungkin pada suatu saat spesies yang ditangkap ini akan punah (Hendri, 2016).

Persawahan daerah Tondano merupakan habitat bagi berbagai jenis hewan diantaranya amphibi. Keanekaragaman amphibi di wilayah ini belum diketahui dengan pasti dan belum pernah dilakukan penelitian sehingga diperlukan melakukan

*Corresponding author: Jurusan Biologi Fakultas Matematika dan Ilmu Pengetahuan Alam Universitas Sam Ratulangi, Jalan Kampus Keleak Manado; Email address: netakares@gmail.com Published by FMIPA UNSRAT (2019) 
penelitian mengenai jenis-jenis amphibi dan sebarannya di dalam kawasan tersebut.

\section{Material dan Metode}

Penelitian ini dilakukan pada bulan DesemberJanuari 2018. Penelitian dilakukan pada tiga lokasi habitat berbeda di areal persawahan Tondano Kabupaten Minahasa Provinsi Sulawesi Utara. Identifikasi dilakukan di Laboratorium Ekologi, Fakultas Matematika dan IImu Pengetahuan Alam, Universitas Sam Ratulangi, Manado dengan menggunakan buku panduan amfibi Jawa dan Bali (Iskandar, 1998). Pengambilan data menggunakan metode Line transek dilakukan dengan cara berjalan sepanjang 300 meter dengan tiga kali pengulangan dan mencatat spesies amphibi. Pengamatan mulai pada pukul 18.00 sampai 22.00 WITA.

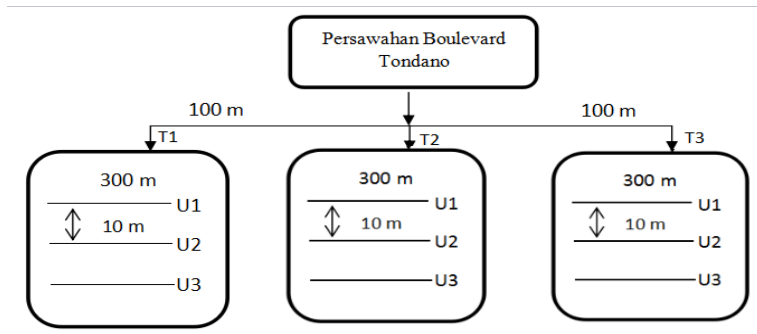

Gambar 1. Bagan peletakan transek pada tiap habitat.

Keanekaragaman amphibian dihitung dengan menggunakan indeks keanekaragaman ShannonWiener (Brower, 1990) dengan rumus sebagai berikut: $\mathrm{H}^{\prime}=-\Sigma \mathrm{Pi} \operatorname{Ln} \mathrm{Pi}$.

\section{Hasil dan Pembahasan}

Beberapa spesies amphibi yang ditemukan di areal penelitian dapat dilihat pada tabel di bawah ini:

\begin{tabular}{lllccc}
\hline \multirow{2}{*}{ No Spesies } & Nama Indonesia & \multicolumn{3}{c}{ Habitat } \\
\cline { 3 - 5 } & & $\begin{array}{c}\text { Persawahan } \\
\text { yang baru } \\
\text { ditanami } \\
\text { padi }\end{array}$ & $\begin{array}{c}\text { Persawahan } \\
\text { yang akan } \\
\text { dipanen }\end{array}$ & $\begin{array}{c}\text { Persawahan } \\
\text { yang } \\
\text { berawa }\end{array}$ \\
\hline 1 & Bufo melanostictus & Bangkong kolong & + & + & + \\
2 & $\begin{array}{l}\text { Hylarana } \\
\text { nicobariensis }\end{array}$ & $\begin{array}{l}\text { Kongkang } \\
\text { jangkrik }\end{array}$ & + & + & - \\
3 & Rana cancrifora & Katak sawah & + & + & + \\
4 & Rana chalconota & Kongkang kolam & - & + & + \\
5 & $\begin{array}{l}\text { Fejevarya } \\
\text { limnocharis }\end{array}$ & Katak tegalan & + & + & + \\
\hline
\end{tabular}

Tabel 1. Daftar spesies katak yang ditemukan di areal persawahan kota Tondano.

Spesies katak yang ditemukan di areal persawahan Tondano mencakup 5 spesies diantaranya yaitu Bufo melanostictus, Hylarana nicobariensis, Rana cancrifora, Rana chalconota dan Fejevarya limnocharis. Berdasarkan hasil pengamatan aktivitas amfibia yang ditemukan kebanyakan menghasilkan suara, berdiam diri, makan dan melakukan aktivitas kawin. Kemunculan spesies pada ketiga habitat berdasarkan tabel di atas menunjukkan bahwa kehadiran spesies di pengaruhi oleh beberapa faktor diantaranya faktor lingkungan dan faktor dari spesies katak itu sendiri.

Nilai indeks Shannon-wiener pada habitat satudi perolehH'=0.782 nilai ini termasuk dalam kategori keanekaragaman rendah. Hal ini dipengaruhi oleh jumlah kahadiran spesies katak pada habitat tersebut yang dimana, kondisi lingkungan mulai menurun. Mengurangnya air dan sumber makanan, sehingga mempengaruhi nilai indeks keanekaragaman pada habitat ini. Kemunculan spesies Bufo melanostictuslebih banyak dibandingkan beberapa spesies lainnya hal ini menunjukkan bahwa spesies ini mampu hidup atau berasosiasi pada semua tipe habitat bahkan habitat yang mengalami gangguan sekalipun (Kusrini dan Remetwa, 2007).

Nilai indeks pada habitat kedua areal persawahan yang siap panen memiliki nilai $\mathrm{H}^{\prime}=1.208$ nilai ini termasuk dalam kategori keanekaragaman sedang. Hal ini disebabkan karena keadaan habitat yang mendukung kehidupan spesies katak untuk dapat hidup pada areal persawahan ini walaupun, pada beberapa titik transek lokasi penelitian terdapat adanya saluran air panas yang dimanfaatkan sebagian masyarakat sebagai tempat aktivitas untuk mencuci sehingga, membuat penurunan kulitas air, dan mempengaruhi standart kulitas air yang dimana habitat air ini sangat disukai oleh spesies katak dan merupakan tempat hidup katak mulai dari fase telur, beludru katak muda hingga katak dewasa, dimana terdapat katak yang menyimpan telurnya di lubang berair pada kayu dan tanah, dipunggung betina atau membawa ke daerah dekat air (Duellman dan Trueb, 1994).

Habitat ketiga yaitu persawahan tidak aktif yang berawa dan bergulma memiliki nilai indeks keanekaragaman yaitu H' 1.139 menunjukan keanakaragaman sedang. Pada lokasi ini dari kelima spesies terdapat satu yang tidak ditemukanya itu Hylarana nicobariensis. Menurut Stoliczka (1870), Spesies H. Nicobariensis merupakan spesies katak yang paling umum di jumpai pada habitat perairan tergenang. Walaupun habitat pada lokasi ini mendukung akan kehadiran spesies ini namun berdasarkan data dari lapangan menunjukkan tidak adanya spesies ini. Ada beberapa faktor yang mempengaruhi kebaradaan spesies. Salah satunya dikarenakan adanya predator pemangsa spesies ini seperti ular, dan tikus sawah. Sementara spesies Bufo melanostictus dapat hidup pada ketiga habitat yang berbeda, hal ini dikarenakan kodok jenis ini dapat hidup pada tersebut. Hal ini didukung oleh pernyataan Iskandar(1998), yang menyatakan bahwa kodok ordo Bufo memiliki asosiasi yang kuat dengan tipe habitat yang terganggu dan selalu berada di dekat hunian manusia.

Meskipun katak merupakan hewan liar yang tidak banyak diminati oleh sebagian masyarakat karena hewan ini memiliki racun yang sangat berbahaya. Namun Katak memiliki banyak manfaat yang baik bagi kehidupan manusia dan secara ekologis dimana katak menjadi salah satu bioindikator perubahan lingkungan (Pough et al., 1998), dan dapat dimanfaatkan sebagai 
penghambat hama serangga vektor penyakit (Stebbins dan Cohen, 1997).

Kesimpulan
Berdasarkan hasil penelitian dapat disimpulkan
bahwa nilai indeks Shannon-wiener amphibi pada
ketiga habitat di areal persawahan Tondano
Kabupaten Minahasa Sulawesi Utara bervariasi,
pada habitat kesatu dengan nilai H'=0.782, habitat
kedua H'=1.208, dan habitat ketiga nilai indeksH'=
1.139. Terdapat 3 spesies yang ditemukan pada
ketiga lokasi sementara 2 diantaranya yaitu $H$.
Nicobariensis tidak ditemukan pada lokasi berawa
sedangkan $R$. Chalconota ditemukan pada lokasi
yang akan dipanen.

\section{Daftar Pustaka}

Brower J. Jernold, Z., Von Ende, C. 1990. Filed and Laboratory Methode for General Ecology. Third Edition. USA: W. M. C. Brown Publisers.

Duellman, W. E. and L. Trueb. 1986. Biology of Amphibians. Mc Graw - Hill Book Company. New York.

Iskandar D. T., 1998. Amfibi Jawa dan Bali. Seri Panduan Lapangan. Puslitbang LIPI, Bogor.

Hendri W. 2016. Inventarisasi Spesies Katak (Ranidae) Sebagai Komoditi Ekspor Di Sumatera Barat. BioCONCETTA. Universitas Bung Hatta, Sumatra Barat.

Kusrini M. D. and R. A. Alford. 2006. Indonesia's exports of frogs' legs. Traffic Bull.

Stuart, S. N., B. E, Young., J. S. Chanson., N. A. Cox., T. M. Boucher. 2004. Status and Trends of Amphibian Declines and Extinction Worldwide Science

Stebbins, R.C. and Cohen, N.W. 1997. A Natural History of Amphibians. New Jersey: Princeton University Press. 